izv. prof. dr. sc. Hrvoje Perčević

Ekonomski fakultet, Sveučilište u Zagrebu, Zagreb, Republika Hrvatska hpercevic@efzg.hr

\title{
KOMPARATIVNI PRIKAZ REGULATIVE SPORAZUMA O TRANSFERNIM CIJENAMA U ZEMLJAMA EUROPSKE UNIJE
}

Primljen: 15. srpnja 2019.

Prihvaćen: 7. listopad 2019.

Pregledni rad

\section{Sažetak}

Transferne cijene su cijene po kojima se odvijaju transakcije između povezanih osoba i to najčešće između povezanih društava koja su članovi iste grupe. Globalizacijom poslovanja i kontinuiranim poslovnim spajanjima društava koja djeluju na globalnom tržištu, transferne cijene postaju značajan instrument alokacije konsolidirane dobiti između povezanih društava u okviru međunarodne grupe. $U$ cilju sprječavanja manipulacija $s$ transfernim cijenama porezne uprave nastoje kontinuirano provoditi nadzor nad transakcijama između povezanih društava i transfernih cijena po kojima se te transakcije realiziraju $i$ to ponajprije analizom i kontrolom dokumentacije o transfernim cijenama sastavljenoj od strane povezanih društava (poreznih obveznika). Međutim, zbog ograničenih resursa porezne uprave nisu u mogućnosti provesti cjelokupan i detaljan nadzor transfernih cijena u svim transakcijama između povezanih društava u okviru svoje jurisdikcije, što porezne uprave suočava s postojanjem značajnog rizika transfernih cijena. Pod rizikom transfernih cijena podrazumijeva se rizik neusklađenosti transfernih cijena $u$ transakcijama između povezanih društava $s$ neovisnim tržišnim načelom $i$ on je svojstven kako poreznim upravama tako i povezanim društvima koja su porezni obveznici. Rizik transfernih cijena kod poreznih obveznika odnosi se na rizik korekcije porezne osnovice i, posljedično, porezne obveze zbog transfernih cijena utvrđenim protivno neovisnom tržišnom načelu. Stoga, i porezne uprave i povezana društva (porezni obveznici) nastoje upravljati rizikom transfernih cijena kako bi ga što je moguće više minimizirali. Jedan od najznačajnijih instrumenata upravljanja rizikom transfernih cijena jesu sporazumi o transfernim cijenama koji se sklapaju između povezanih društava (poreznih obveznika) i jedne ili više poreznih uprava. Sporazumom o transfernim 
cijenama unaprijed se definiraju pretpostavke, uvjeti, kriteriji i metode određivanja transfernih cijena $u$ specificiranim transakcijama između povezanih društava za određeno vremensko razdoblje čime se značajno minimizira rizik transfernih cijena i kod poreznih obveznika i kod poreznih uprava.

U ovom rada analizira se i sistematizira mogućnost i dostupnost sporazuma o transfernim cijenama u zemljama Europske unije te istražuje u kojoj mjeri postoji usklađenost regulative sporazuma o transfernim cijenama $u$ zemljama Europske unije. Rezultati istraživanja su pokazali da je u većini zemalja članica Europske unije regulatornim okvirom omogućena primjena sporazuma o transfernim cijenama te da su u većini zemalja Europske unije dostupne sve tri vrste sporazuma o transfernim cijenama. Zemlje Europske unije se u pogledu regulative razlikuju u obračunavanju naknada za sklapanje sporazuma o transfernim cijenama te u pogledu vremenskog trajanja procesa sklapanja sporazuma o transfernim cijenama.

Ključne riječi: sporazumi o transfernim cijenama, transferne cijene, povezana društva, rizik transfernih cijena, porezna uprava

JEL: M40, M41

\section{UVOD}

U suvremenim uvjetima globalizacije poslovanja poslovni subjekti su izloženi brojnim rizicima, a jedan od značajnijih rizika s kojim se suočavaju poslovni subjekti koji su bili sudionikom poslovnih spajanja i koji provode transakcije sa svojim povezanim društvima bilo na nacionalnoj bilo na međunarodnoj razini, jest rizik transfernih cijena. S aspekta poslovnih subjekata rizik transfernih cijena jest rizik vezan za potencijalu korekciju transfernih cijena zaračunatih u transakcijama $s$ povezanim društvima od strane porezne uprave koja rezultira korekcijom porezne osnovice te porezne obveze. Poslovni subjekti nastoje upravljati rizikom transfernih cijena kako bi se zaštitili od potencijalnih korekcija poreznih obveza, ali i potencijalnih sporova vezanih za područje transfernih cijena. Rizik transfernih cijena je specifičan po tome što se on ne odnosi samo na poslovne subjekte - porezne obveznike, već i na nacionalne porezne uprave. Sa stajališta porezne uprave, rizik transfernih cijena predstavlja rizik da određene transferne cijene $u$ transakcijama s povezanim društvima nisu 
usklađene $\mathrm{s}$ tržišnim načelima. $\mathrm{S}$ obzirom da nacionalne porezne uprave imaju ograničene resurse u pogledu nadzora transfernih cijena i, općenito, transakcija između povezanih društava, porezne uprave također nastoje upravljati rizikom transfernih cijena $\mathrm{i}$ to na način da procjenjuju rizik transfernih cijena za svaki pojedini slučaj te se nadzor pokreće samo kod onih poslovnih subjekata (poreznih obveznika) kod kojih je procijenjen visoki rizik transfernih cijena te značajan potencijalni iznos povrata poreza na ime korekcije transfernih cijena.

U cilju učinkovitijeg upravljanja rizikom transfernih cijena te minimizacije sporova vezanih uz područje transfernih cijena, poslovni subjekti (porezni obveznici) koji su izloženi riziku transfernih cijena te pojedine nacionalne porezne uprave koriste sporazume o transfernim cijenama kao instrument upravljanja rizikom transfernih cijena. Sporazumi o transfernim cijenama pojavili su se početkom 90tih godina prošlog stoljeća u SAD-u kao alternative procesima rješavanja sporove vezanih uz područje transfernih cijena između poslovnih subjekata (poreznih obveznika) i službe za unutarnje prihode (Internal Revenue Service). Ovim sporazumima definiraju se ključni parametri, uvjeti i okolnosti pod kojima se određuju i primjenjuju transferne cijene u unaprijed definiranim transakcijama između povezanih društava tijekom definiranog vremenskog razdoblja. $\mathrm{Na}$ taj način sporazumima o transfernim cijenama se, sa strane poslovnog subjekta (poreznog obveznika), osigurava priznavanje transfernih cijena za porezne svrhe, a poreznim upravama olakšava nadzor transfernih cijena $u$ transakcijama između povezanih društava te učinkovitost korištenja resursa. Sporazumi o transfernim cijenama su stekli veliku popularnost i u zemljama Europske unije, gdje njihov broj intenzivno raste. Intenzitet primjene sporazuma o transfernim cijenama u zemljama Europske unije se $\mathrm{u}$ posljednjim godinama povećava prvenstveno zahvaljujući uvođenju regulative o sporazumima o transfernim cijenama u državama članicama istočne i jugoistočne Europe. Također, značajnost sporazuma o transfernim cijenama se povećava uslijed realizacije OECD-ovog projekta o smanjivanju porezne osnovice i premještanju dobiti (Base Erosion and Profit Shifting BEPS) kojim se omogućilo zemljama u razvoju razvijanje primjerenog instrumentarija i regulatornog okvira za nadzor transfernih cijena što je rezultiralo pojačanim nadzorom transfernih cijena $u$ tim zemljama. S obzirom na pojačani nadzor transfernih cijena od strane zemalja u razvoju, intenziviraju se i sporovi između poreznih uprava i poslovnih subjekata (poreznih obveznika) vezanih uz pitanje transfernih cijena. Sporovi vezani za područje transfernih cijena na međunarodnoj razini mogu se učinkovito rješavati sporazumima o transfernim cijenama, budući da je je 
implementacija takvih sporazuma često troškovno i vremenski isplativija nego prikupljanje sveobuhvatne dokumentacije u procesu nadzora transfernih cijena od strane porezne uprave.

U ovom radu analizira se regulatorni okvir transfernih cijena u zemljama članicama Europske unije $\mathrm{s}$ ciljem utvrđivanja postojanja regulative i mogućnosti primjene sporazuma o transfernim cijenama, utvrđuju se vrste sporazuma o transfernim cijenama koje je moguće sklopiti u pojedinim zemljama članicama, postojanje naknade za sklapanje sporazume te prosječno vrijeme trajanja sklapanja sporazuma. Ne temelju ovih parametara utvrđuje se razina usklađenosti regulative i mogućnosti primjene sporazuma o transfernim cijenama u zemljama Europske unije.

\section{TEORIJSKI OKVIR I PREGLED LITERATURE}

\subsection{Koncept i svrha sporazuma o transfernim cijenama}

Koncept sporazuma o transfernim cijenama razvijen je u SAD-u 1991. godine temeljem Revenue Procedure 91-22 od strane američke Službe unutarnjih prihoda (Internal Revenue Service - IRS) kao alternativa dotadašnjim mehanizmima nadzora i rješavanja sporova vezanih za pitanja transfernih cijena. Naime, 80tih godina prošlog stoljeća IRS je intenzivirala nadzor transfernih cijena $u$ transakcijama između povezanih društava, $i$ to posebno na međunarodnoj razini, što je rezultiralo značajnim povećanjem sporova vezanih za pitanja transfernih cijena između poreznih obveznika i IRS-a (KPMG, 2017., str. 7.). Pojačani nadzor transfernih cijena od strane IRS-a imao je značajne implikacije i na samu IRS i na poslovne subjekte koji su bili predmetom nadzora. S aspekta IRS-a, intenziviranje nadzora transfernih cijena crpilo je ionako oskudne resurse IRS-a, dok je s aspekta poslovnih subjekata to intenziviranje uzrokovalo dodatne napore $u$ pripremanju opsežne dokumentacije za dokazivanje usklađenosti transfernih cijena s tržišnim načelima. Iz tog razloga, poslovni subjekti (porezni obveznici) koji su bili predmetom nadzora, zahtijevali su od IRS-a alternativni pristup za usklađivanje transfernih cijena $\mathrm{s}$ tržišnim načelima (KPMG, 2017., str. 7.) koji je operacionaliziran u obliku razvoja programa odnosno koncepta sporazuma o transfernim cijenama 1991. godine. Nakon implementacije koncepta sporazuma o transfernim cijenama u SAD-u, taj koncept su, po uzoru na SAD, počele preuzimati i druge zemlje te se njegova primjena počela širiti na međunarodnoj razini i to uglavnom kod 
poslovnih subjekata koji su bili članovi međunarodnih grupa. Konačnom koncept sporazuma o transfernim cijenama uključen je i u Smjernice o transfernim cijenama za multinacionalne kompanije i porezne uprave Organizacije za ekonomsku suradnju i razvoj (OECD) koje su danas općeprihvaćeni međunarodni standard za regulaciju, određivanje i nadzor transfernih cijena.

Sporazum o transfernim cijenama je sporazum kojim se, prije nastanka kontroliranih transakcija, određuje set kriterija (poput metode određivanja transfernih cijena, usporedna i primjerena usklađenja te ključne pretpostavke budućih događaja) za određivanje transfernih cijena za te transakcije tijekom određenog razdoblja (OECD, 2017., str. 214.). Intencija razvoja i implementacije koncepta sporazuma o transfernim cijenama zamišljena je kao zamjena tradicionalnim administrativnim, pravnim i sporazumnim mehanizmima rješavanja pitanja vezana za transferne cijene i to posebno u onim slučajevima kada ti tradicionalni mehanizmi ne uspiju riješiti određena pitanja vezana uz transferne cijene ili je te mehanizme $u$ tim slučajevima vrlo teško primijeniti. Sporazum o transfernim cijenama formalno inicira porezni obveznik koji je predmetom nadzora vezanim za pitanje transfernih cijena. Iniciranjem sporazuma porezni obveznik formalno zahtijeva pregovore između poreznog obveznika, jednog ili više povezanih društava te jedne ili više poreznih uprave o transfernim cijenama po kojima se odvijaju određene transakcije između povezanih društava (OECD, 2017., str. 214.).

S obzirom da se sporazumom o transfernim cijenama unaprijed određuje set kriterija za određivanje transfernih cijena u unaprijed određenim transakcijama između povezanih društava, taj sporazum uobičajeno uključuje predviđanja o budućim događajima, a o pouzdanosti tih predviđanja ovisi i pouzdanosti i primjenjivost sporazuma o transfernim cijenama kao instrumenta upravljanja rizikom transfernim cijenama. Nepouzdana predviđanja ne smiju biti uključena u sporazum o transfernim cijenama, a pouzdanost predviđanja procjenjuje se i analizira u postupku pregovaranja i sklapanja sporazuma o transfernim cijenama. U postupku pregovaranja i sklapanja sporazuma o transfernim cijenama ključna je suradnja povezanih društava koja međusobno provode transakcije za koje se određuju i ugovaraju transferne cijene. Povezana društva moraju upoznati poreznu uprava s metodologijom određivanja transfernih cijena za koju ona smatraju da je najprimjerenija s obzirom na sve poslovne činjenice i okolnosti te predati poreznoj upravi dokumentaciju koja podupire primjerenost te metodologije. Dokumentacija koju povezana društva 
dostavljaju poreznoj upravi sadrži informacije o djelatnosti povezanih društava, tržišta na kojima povezana društva posluju te zemlje koje je potrebno uključiti u sporazum. Osim toga, povezana društva moraju identificirati i navesti u dokumentaciji transakcije između nepovezanih društava u identičnim ili sličnim ekonomskim i tržišnim uvjetima i okolnostima koje su usporedive s kontroliranim transakcijama između povezanih društava čije transferne cijene su predmetom sporazuma te provesti funkcijsku analizu tih transakcija. Nakon završetka procesa pregovaranja i sklapanja sporazuma o transfernim cijenama, porezne uprave osiguravaju potvrdu povezanim društvima u njihovim jurisdikcijama da neće biti korekcija transfernih cijena u kontroliranim transakcijama sve dok se povezana društva pridržavaju uvjeta sporazuma o transfernim cijenama. Sporazum o transfernim cijenama uobičajeno uključuje i klauzulu o mogućim izmjenama ili otkazivanju sporazuma u slučajevima značajnih promjena poslovnih aktivnosti ili promjena ekonomskih uvjeta i okolnosti koje značajno utječu na pouzdanost primijenjene metodologije određivanja transfernih cijena (OECD, 2017. str. 217.).

Sporazum o transfernim cijenama može pokrivati sva pitanja transfernih cijena poreznog obveznika, ali se poreznom obvezniku može pružiti fleksibilnost da zahtjeve za sporazumom o transfernim cijenama podnese samo za transakcije s određenim povezanim društvom ili samo za određene transakcije sa svim povezanim društvima. Povezana društva mogu zahtjev za sporazumom podnijeti za utvrđena buduća porezna razdoblja, iako koncept sporazuma o transfernim cijenama pruža mogućnost primjene dogovorene metodologije određivanja transfernih cijena za rješavanje otvorenih pitanja i sporova između poreznog obveznika i porezne uprave iz prethodnih poreznih razdoblja, međutim ta mogućnost zahtijeva dogovor između poreznog obveznika, porezne uprave i ostalih sporazumnih strana (OECD, 2017. str. 217.).

Svaka porezna uprava koje je ugovorna strana sporazuma o transfernim cijenama nadzire poštivanje uvjeta sporazuma i to na dva načina: (a) zahtjevom da porezni obveznik koji je sklopio sporazum preda godišnje izvještaje kojima prikazuje poštivanje uvjeta sporazuma kao i relevantnost ključnih pretpostavki ugovora te (b) kontinuiranim nadzorom poreznog obveznika kao dijela uobičajenih nadzornih ciklusa, ali bez ponovne procjene metodologije određivanja transfernih cijena, već usmjeravanjem ispitivanja transfernih cijena samo na potvrđivanje polaznih podataka relevantnih za prijedlog sporazuma te na određivanje poštivanja uvjeta sporazuma od strane poreznog obveznika. Porezna uprava može ispitivati 
pouzdanost i točnost podataka u sporazumu i u godišnjim izvještajima poreznog obveznika kao i točnost i konzistentnost primjene određene metodologije transfernih cijena (OECD, 2017., str. 218.). U slučaju prijevara, pogrešnog tumačenja uvjeta sporazuma o transfernim cijenama kao i nepoštivanja uvjeta sporazuma od strane poreznog obveznika, sporazum o transfernim cijenama se može otkazati, čak i retroaktivno. Porezna uprava koja pokreće prijedlog otkazivanja sporazuma odnosno koja otkazuje sporazum, mora o svojim namjerama i razlozima otkazivanja obavijestiti ostale porezne uprave koje su strane u sporazumu o transfernim cijenama (OECD, 2017., str. 218.).

\subsection{Vrste sporazuma o transfernim cijenama}

Sporazumi o transfernim cijenama mogu se sklopiti kao: (a) jednostrani ili unilateralni, (b) dvostrani ili bilateralni i (c) višestrani ili multilateralni (OECD, 2107. str. 215. i 216.). Jednostrani sporazumi o transfernim cijenama su sporazumi koje dogovaraju porezni obveznik i porezna uprava u njenoj jurisdikciji bez sudjelovanja drugih zainteresiranih strana. Ovakvi jednostrani sporazumi o transfernim cijenama mogu minimizirati odnosno eliminirati rizik transfernih cijena isključivo na području jurisdikcije one porezne uprave s kojom je taj sporazum sklopljen, ali ostavljaju otvoren rizik u drugim poreznim jurisdikcijama u kojima djeluju povezana društva čija je međusobna transakcija predmetom jednostranog sporazuma o transfernim cijenama. Iz tog razloga jednostrani sporazumi o transfernim cijenama ne eliminiraju mogućnost dvostrukog oporezivanja ili neoporezivanja, pa ih mnogi porezni obveznici izbjegavaju ili zahtijevaju uključivanje odnosnih poreznih uprava u sporazum. Upravo zbog problema s dvostrukim oporezivanjem većina zemalja preferira dvostrane i višestrane sporazume o transfernim cijenama, a u pojedinim zemljama jednostrani sporazumi nisu čak ni dozvoljeni (npr. Švedska i Irska). Dvostrani sporazumi o transfernim cijenama su sporazumi u kojima se dvije zemlje (odnosno njihove porezne uprave) usuglašavaju o metodologiji transfernih cijena u kontroliranim transakcijama između povezanih društava, dok su višestrani sporazumi oni u kojima se usuglašava više zemalja (odnosno njihovih poreznih uprava). Dvostrani i višestrani sporazumi o transfernim cijenama u značajnoj mjeri minimiziraju odnosno eliminiraju rizik transfernih cijena, a posljedično i mogućnost dvostrukog oporezivanja te doprinose većoj sigurnosti poreznih obveznika u pogledu priznavanja transfernih cijena u porezne svrhe (OECD, 2017., str. 216.). 
Povećanju atraktivnosti dvostranih i višestranih sporazuma o transfernim cijenama doprinio je i OECD-ov BEPS projekt u okviru kojeg je preporučeno da zemlje implementiraju dvostrane sporazume o transfernim cijenama čim steknu kapacitet za njihovu implementaciju, budući da dvostrani sporazumi o transfernim cijenama pružaju veću razinu sigurnosti za sve sporazumne partnere, smanjuju mogućnost dvostrukog oporezivanja te pro aktivno sprječavaju sporove vezane za transferne cijene (OECD, 2013., str. 23. i 24.; OECD, 2017., str. 214.). Nakon implementacije BEPS projekta, potreba za primjenom sporazuma o transfernim cijenama se na globalnoj razini intenzivirala, s obzirom da su zemlje u razvoju (kao rezultat BEPS projekta) implementirala regulatorni okvir i mehanizme nadzora transfernih cijena u svojim jurisdikcijama, a sporazumi o transfernim cijenama u značajnoj mjeri osiguravaju zaštitu od rizika transfernih cijena (KPMG, 2017., str. 3.).

\subsection{Proces pregovaranja sporazuma o transfernim cijenama}

Postupak pregovaranja i sklapanja sporazuma o transfernim cijenama varira $\mathrm{u}$ ovisnosti od procedure određene u pojedinim zemljama i o složenosti slučaja transfernih cijena odnosno složenosti transakcija između povezanih društava u okviru kojih se određuju transferne cijene. Jednostavniji slučajevi transfernih cijena, u pravilu, zahtijevat će kraće vremensko razdoblje pregovaranja i sklapanja sporazuma o transfernim cijenama, dok će složeniji slučajevi zahtijevati dulje vremensko razdoblja. Svaka zemlja odnosno svaka nacionalna porezna uprava propisuje proceduru pregovaranja i sklapanja sporazuma o transfernim cijenama. U SAD-u IRS provodi postupak sklapanja dvostranog ili višestranog sporazuma o transfernim cijena kroz sljedećih pet faza: (1) strategija sporazuma o transfernim cijenama i analiza transfernih cijena; (2) konferencija prije formalnog podnošenja zahtjeva; (3) formalni zahtjev za sporazumom o transfernim cijenama; (4) evaluacija i pregovaranja sporazuma o transfernim cijenama i (5) primjena i provedba ugovora. Tijekom napredovanja procesa komunikacija između poreznog obveznika i porezne uprave prelazi s opće rasprave o obveznikovoj industriji i poslovanju prema analizi specifičnih obveznikovih transakcija koje su predmetom sporazuma odnosno konkretnije, od pregovaranja o primjerenosti odabranog cjenovnog pristupa i odabira usporedivih društava do sastavljanja i primjene sporazuma o transfernim cijenama (KPMG, 2017., str. 9.). U okviru prve faze pregovaranja sporazuma, prikupljaju se podaci o poslovanju poreznog obveznika, provodi se funkcijska i ekonomska analiza te se određuje 
strategija sporazuma o transfernim cijenama. U drugoj fazi priprema se prikupljena relevantna dokumentacija prije formalnog podnošenja zahtjeva za sporazumom o transfernim cijenama te se inicira sastanak sa stranom poreznom upravom u kojoj djeluju odnosno povezano društvo s kojim porezni obveznik provodi transakciju, ukoliko je riječ o dvostranom sporazumu. U trećoj fazi priprema se i podnosi formalni zahtjev za sporazumom o transfernim cijenama te se izdaje obavijest o primitku zahtjeva od strane porezne uprave. Četvrta faza je ključna faza pregovaranja sporazuma o transfernim cijenama i ona započinje inicijalnim sastankom poreznog obveznika, nacionalne i strane porezne uprave na kojem porezni obveznik prima inicijalna pitanja poreznih uprava vezana za slučaj transfernih cijena. Nakon odgovora na postavljena inicijalna pitanja poreznih uprava, slijede posjete i dodatna pitanja poreznih uprava koja se odnose na specifične transakcije i metodologiju određivanja transfernih cijena. Nakon zaprimanja odgovara na dodatna pitanja poreznih uprava, slijedi sastanak poreznog obveznika, nacionalne i strane porezne uprave na kojem se razmatraju pozicije poreznog obveznika i pozicije poreznih uprava da bi se nakon čega se provode pregovori s nadležnim tijelima poreznih uprava. U petoj fazi zaključuje se sporazum o transfernim cijenama te se isti potpisuje između poreznog obveznika, nacionalne i strane porezne uprave (KPMG, 2017., str. 9.). Potpisivanjem sporazuma o transfernim cijenama, sporazum stupa na snagu i sve sporazumne strane su dužne poštivati ugovorne odredbe sporazuma.

Ovaj prezentirani hodogram aktivnosti pregovaranja i sklapanja sporazuma transfernim cijenama je uobičajen u okviru američke IRS i on se može u određenoj mjeri razlikovati u pojedinim nacionalnim poreznim upravama. Ipak ključne faze ovog procesa (prikupljanje podataka, priprema i analiza dokumentacije, razmatranje predložene metodologije transfernih cijena i diskutiranje te zaključenje i potpisivanje sporazuma) su prisutne kod svake procedure pregovaranja i sklapanja sporazuma o transfernim cijenama.

U Republici Hrvatskoj Zakonom o porezu na dobit od 01.01.2016. godine omogućena je primjena sporazuma o transfernim cijenama te je sukladno odredbama Zakona o porezu na dobit (čl. 14a) u 2017. godini donesen Pravilnik o postupku sklapanja prethodnog sporazuma o transfernim cijenama. Sukladno odredbama Pravilnika o postupku sklapanja prethodnog sporazuma o transfernim cijenama porezni obveznici mogu sklapati jednostrane, dvostrane i višestrane sporazuma (Pravilnik o postupku sklapanja prethodnog sporazuma o transfernim cijenama, čl. 1.), a sam postupak sklapanja sporazuma se provodi kroz sljedeće faze: (a) podnošenje 
inicijative za sklapanje sporazuma; (b) prethodni razgovor; (c) podnošenje izjave o namjeri sklapanja sporazuma; (d) sklapanje sporazuma i (e) praćenje provedbe sporazuma (Pravilnik o postupku sklapanja prethodnog sporazuma o transfernim cijenama, čl. 4., 2017.). u prvoj fazi porezni obveznik upućuje pisanu izjavu o namjeri sklapanja sporazuma o transfernim cijenama prije nastanka predmetne transakcije. U drugoj fazi porezna uprava poziva poreznog obveznika na prethodni razgovor kojim se razmjenjuju mišljenja i dobivaju informacije i pojašnjenja o svrsi i cilju sklapanja sporazuma, metodologiji utvrđivanja transfernih cijena i i sličnim i ostalim relevantnim čimbenicima bitnim za sklapanje sporazuma. Nakon prethodnog razgovora, porezni obveznik podnosi izjavu o namjeri sklapanja sporazuma koja se sastoji od općih i specifičnih podataka o predmetnim transakcijama i uključenom poreznom obvezniku i njegovim povezanim društvima. Nakon pribavljanja cjelokupne dokumentacije te usuglašavanja stavova poreznog obveznika i porezne uprave, sklapa se sporazum o transfernim cijenama i određuje početak njegove primjene te rok na koji se sklapa. U zadnjoj fazi procesa porezna uprava prati provedbu sporazuma (Bakran et al., 2018., str. 226.) sve dok porezni obveznik poštuje uvjete sporazuma, porezna uprava neće zahtijevati korekciju transfernih cijena. Poštivanje uvjeta sporazuma porezni obveznik dokazuje podnošenjem godišnjeg izvješća o provedbi sporazuma o transfernim cijenama (Bakrane $\mathrm{t}$ al., 2018., str. 226.).

Postupak sklapanja sporazuma o transfernim cijenama u Republici Hrvatskoj vrlo je sličan postupku u SAD-u.

\subsection{Prednosti i nedostaci sporazuma o transfernim cijenama}

Sporazumi o transfernim cijenama su učinkovit instrument upravljanja rizikom transfernih cijena kako s aspekta poslovnog subjekta (poreznog obveznika) koji provodi transakcije s povezanim društvima tako i s aspekta porezne uprave. Iako sporazumi o transfernim cijenama imaju, neosporno, značajne prednosti, oni isto tako imaju i određene nedostatke koji su uočeni tijekom njihove primjene $u$ različitim poreznim jurisdikcijama. Najznačajnija prednost sporazuma o transfernim cijenama jest sigurnost poreznog tretmana transfernih cijena $u$ transakcijama između povezanih društava koje su obuhvaćene sporazumom, ukoliko porezni obveznik poštuje sporazumne uvjete. Također, istekom vremenskog razdoblja na koje je sporazum sklopljen, sporazum se može produžiti, ukoliko se nisu promijenili ekonomski uvjeti i okolnosti ili obnoviti odnosno ponovno 
zaključiti pri čemu je postupak pregovaranja puno jednostavniji i kraće nego prilikom prvotnog sklapanja, budući da porezne uprave koje su sporazumne strane imaju većinu potrebnih podataka o poreznom obvezniku. Sporazum o transfernim cijenama poreznim obveznicima omogućuje objektivnije predviđanje poreznih obveza. Osim toga, sporazum o transfernim cijenama pruža mogućnost konzultacija i suradnje poreznog obveznika i porezne uprave u nekonkurentskom duhu i okruženju, u okviru kojega je olakšan slobodan tijek informacija potrebnih za razmatranje i objektivno rješavanje kompleksnih poreznih pitanja vezanih za transferne cijene. Prednost sporazuma o transfernim cijenama očituje se i u nižim troškovima, manjem korištenju resursa, kako poreznog obveznika tako i porezne uprave, te kraćim vremenskim razdobljem nadziranja transfernih cijena u odnosu na klasičan nadzor transfernih cijena. Osim toga, sporazumi o transfernim cijenama sprječavaju dugotrajne sudske sporove koji se odnose na pitanja transfernih cijena (OECD, 2017., str. 219. i 220.).

Dvostrani i višestrani sporazumi o transfernim cijenama imaju prednost $u$ odnosu na jednostrane sporazume, jer u njima sudjeluju sve relevantne porezne uprave što u značajnoj mjeri omogućava umanjenje ili eliminiranje mogućnosti dvostrukog oporezivanja ili neoporezivanja. Kod jednostranih sporazuma o transfernim cijenama kao sporazumna strana sudjeluje samo jedna porezna uprava te takvi sporazumi ne osiguravaju izbjegavanje dvostrukog oporezivanja, jer se ne primjenjuju u drugim poreznim upravama u čijim jurisdikcijama djeluju povezna društva s kojim porezni obveznik provodi kontrolirane transakcije (OECD, 2017., str. 220.).

Sporazumi o transfernim cijenama pružaju poreznim upravama uvid u kompleksne međunarodne transakcije koje se provode $\mathrm{u}$ okviru velikih međunarodnih grupa te pristup korisnim podacima o pojedinim industrijama i primijenjenim cjenovnim metodologijama što u konačnici rezultira boljim razumijevanjem i objektivnijim poreznim tretmanom kompleksnih međunarodnih transakcija između povezanih društava (OECD, 2017., str. 221.).

Usprkos brojnim i neospornim prednostima, sporazumi o transfernim cijenama imaju i određenih nedostataka. Već je istaknuto da jednostrani sporazumi o transfernim cijenama ne osiguravaju izbjegavanje dvostrukog oporezivanja međunarodne grupe, budući da oni nisu prihvaćeni u drugim poreznim upravama te mogu uzrokovati dugotrajne i financijski izdašne sudske sporove u području transfernih cijena. Sporazumi o transfernim cijenama mogu sadržavati nepouzdana predviđanja promjena tržišnih uvjeta koja rezultiraju neobjektivnim poreznim tretmanom transakcija između povezanih društava. Postupak pregovaranja i sklapanja sporazuma o 
transfernim cijenama može biti dugotrajan i zahtjevan, stvarajući dodatni pritisak na oskudne resurse poreznih uprava (OECD, 2017. str. 221.). Osim toga, prilikom produženja postojećih dvostranih sporazuma o transfernim cijenama u okviru međunarodne grupe te sklapanja novih sporazuma u okviru te iste grupe, moguće je da se sporazumi ugovoriti temeljem prethodno utvrđenih ekonomskih uvjeta i okolnosti na postojećim tržištima, bez dodatne analize uvjeta i okolnosti koji vladaju na drugim tržištima. Iako sporazumi o transfernim cijenama umanjuju rizik transfernih cijena, oni porezne obveznike ne štite u potpunosti od nadzora transfernih cijena, budući da on i dalje mora dokazivati poštivanje sporazumnih odredbi (OECD, 2017., str. 223.). U postupku pregovaranja i sklapanja sporazuma o transfernim cijenama porezna uprava prikuplja značajne i opsežne informacije o poreznom obvezniku za koje postoji mogućnost zloupotrebljavanja i neovlaštenog širenja, bez obzira što, u svakoj zemlji, postoji obveza čuvanja i pravo povjerljivosti prikupljenih informacija. Postupak pregovaranja i sklapanja sporazuma o transfernim cijenama može biti skup i dugotrajan tako da ga mali porezni obveznici s ograničenim financijskim resursima ne mogu koristiti. Kao rezultat toga, sporazume o transfernim cijenama uglavnom koriste veliki porezni obveznici za rješavanje kompleksnih slučajeva transfernih cijena. Osim toga, zbog ograničenosti resursa poreznih uprava moguće je ograničenje broja zahtjeva za sporazumima o transfernim cijenama koje porezne uprave mogu obaviti (OECD, 2017., str. 224.).

\subsection{Pregled dosadašnjih relevantnih istraživanja}

Brojni istraživači su provodili istraživanja vezana za šire područje transfernih cijena. U ovom dijelu radu navedeni su i sistematizirani rezultati prethodno provedenih istraživanja koji se odnose na primjenu, učinke te prednosti i nedostatke sporazuma o transfernim cijenama. Hickman (1998) je u svom radu razmatrala pitanje javnog objavljivanja sporazuma o transfernim cijenama i analizirala argumente za i protiv objavljivanja sporazuma na temelju studije slučaja. Temeljem provedene studije slučaja, Hickman je zaključila da se sporazumi o transfernim cijenama ne bi trebali javno objavljivati, s obzirom na sve informacije o poslovnim subjektima i njihovim povezanim društvima koji su u tom sporazumu navedene. Hickman je također istaknula da sporazumi o transfernim cijenama nisu konačno rješenje, već privremeno rješenje za kompleksna pitanja transfernih cijena u transakcijama između međunarodno povezanih društava s kojima se suočavaju porezne uprave. Ona je također konstatirala da su se sporazumi o 
transfernim cijenama dokazali kao učinkovita alternativa dosadašnjim sudskim parnicama i nesigurnostima vezanim uz transferne cijene koje su postojale prije razvoja koncepta sporazuma o transfernim cijenama. Prema Hickman, jedna od najvećih prednosti sporazuma o transfernim cijenama je uspostavljanje suradnje između poreznih uprava i poreznih obveznika što smatra polaznom točkom za provođenje istinske reforme na međunarodnoj razini (Hickman, 1998., str. 194.).

Borkowski (2000) je provela detaljnu analizu statusa sporazuma o transfernim cijenama u izabranim zemljama. S obzirom da su sporazumi o transfernim cijenama učinkovita strategija smanjivanja rizika transfernih cijena, Borkowski je analizirala proceduru, troškove, poteškoće i vrijeme trajanja pregovaranja i sklapanja sporazuma o transfernim cijenama u 27 izabranih zemljama svijeta. Temeljem provedene analize zaključila je da, iako većina analiziranih zemalja ima formalne ili neformalne programe sklapanja sporazuma o transfernim cijenama, procedura, troškovi, poteškoće i vrijeme trajanja sklapanja sporazuma nisu konzistentni u promatranim zemljama te da su u tom području nužna usklađivanja na međunarodnoj razini (Borkowski, 2000., str. 2.).

Fan (2008) je identificirao i analizirao poteškoće u primjeni sporazuma o transfernim cijenama $i$ Kini. Iako zakonska regulativa $u$ području oporezivanja dobiti poslovnih subjekata u Kini omogućava primjenu sporazuma o transfernim cijenama, postoje određene poteškoće i problemi u široj primjeni tih sporazuma u Kini. Fan je identificirao sljedeće poteškoće šire primjene sporazuma o transfernim cijenama u Kini: (a) visoki troškovi sklapanja sporazuma o transfernim cijenama; (b) složeni proces pregovaranja sporazuma o transfernim cijenama; (c) kratko razdoblja trajanja sporazuma; (d) velike poteškoće u utvrđivanju ključnih pretpostavki i uobičajenih transakcijskih cijena za utvrđivanje pokazatelja profitabilnosti; (d) ograničenja u administriranju sporazuma i (e) objavljivanje povjerljivih informacija poreznim vlastima u postupku pregovaranja sporazuma o transfernim cijenama. Kako bi se premostile identificirane poteškoće i omogućila šira primjena sporazuma o transfernim cijenama u Kini, Fan predlaže sljedeće: (a) pojednostavljene procedure sporazuma o transfernim cijenama; (b) postavljanje što je moguće objektivnijih pretpostavki $u$ sporazumu o transfernim cijenama; (c) pojednostavljenje postupka administriranja sporazuma o transfernim cijenama pod čime se podrazumijeva postavljanje jednostavne metode sporazuma o transfernim cijenama, skupno upravljanje sporazumima o transfernim cijenama, dodavanje odgovornosti poreznih obveznika za dokaze ispunjavanja uvjeta 
sporazuma i dodavanje procedure rješavanja kontroverzi između porezne uprave i poreznog obveznika u postupku pregovaranja i provođenja sporazuma o transfernim cijenama i (d) poštivanje i zaštita poslovnih tajni poreznih obveznika (Fan, 2008., str. 54. - 57.).

Kortebusch (2014) je razmatrala uvjete i okolnosti u kojima multinacionalne kompanije trebaju zahtijevati sklapanja sporazuma o transfernim cijenama. Njezino istraživanje je bilo usmjereno na multinacionalne kompanije koje investiraju u ovisno društvo u zemlji s niskim poreznim opterećenjem. $\mathrm{Na}$ temelju rezultata svojeg istraživanja Kortebusch je zaključila da multinacionalne kompanije trebaju zahtijevati sklapanje sporazuma o transfernim cijenama u slučajevima kada postoji mogućnost visokog dvostrukog oporezivanja i kada se stope poreza na dobit u zemljama u kojima djeluje multinacionalna kompanija i njezino ovisno društvo značajno razlikuju. Kortebusch je također zaključila da povećanje dvostrukog oporezivanja i povećanje razlika u stopama poreza na dobit između različitih zemalja povećavaju atraktivnost sporazuma o transfernim cijenama (Kortebusch, 2014., str. 4.).

Osborn i Khripounova (2016) su razmatrali primjenu sporazuma o transfernim cijenama u uvjetima nakon implementacije OECD-ovog projekta umanjenja porezne osnovice i premještanja dobiti (BEPS projekt) . Prema njihovom mišljenju implementacija zahtjeva OECD-ovog BEPS projekata, koja je u značajnoj mjeri izmijenila OECD-ove smjernice o transfernim cijenama za multinacionalne kompanije i porezne uprave, će značajno povećati atraktivnost i primjenu dvostranih sporazuma o transfernim cijenama među multinacionalnim kompanijama kako bi izbjegli nesigurnosti u pogledu poreznog tretmana transfernih cijena po kojima provode transakcije sa svojim povezanim društvima. Naime, promjene $u$ OECD-ovim smjernicama o transfernim cijenama uzrokovane implementacijom zahtjeva akcija 8 -10 BEPS projekta, daju nove poticaje poreznim upravama za razmatranje, ne samo cijena po kojima se provode transakcije između povezanih društava, već i mogućnost priznavanje takvih transakcija u svrhu oporezivanja. S obzirom da će ove promjene vrlo vjerojatno dovesti do nekonzistentnosti u pogledu stava i karakterizacije ovakvih transakcija od strane nacionalnih poreznih uprava, kao posljedica primjene izmijenjenih smjernica o transfernim cijenama pojavit će se mogućnost dvostrukog oporezivanja. U cilju izbjegavanja rizika dvostrukog oporezivanja multinacionalne kompanije će intenzivnije početi podnositi zahtjeve za sklapanjem i primjenom dvostranih i višestranih sporazuma o transfernim cijenama, budući da, u ovakvim okolnostima, dvostrani i 
višestrani sporazumi o transfernim cijenama mogu biti izrazito učinkovit instrument zaštite od dvostrukog oporezivanja (Osborn i Khripounova, 2016., str. 1179.).

Ignat (2017) je u svom radu sistematizirala i prezentirala osnovne prednosti i nedostatke sporazuma o transfernim cijenama u odnosu na dokumentaciju o transfernim cijenama, ilustrirala praktični primjer slučaja dvostrukog oporezivanja te prikazala komparativnu analizu između broja odobrenih sporazuma o transfernim cijenama i broja sklopljenih ugovora o izbjegavanju dvostrukog oporezivanja u zemljama Europske unije. Rezultati njezinog istraživanja su pokazali da sporazumi o transfernim cijenama imaju više prednosti u odnosu na dokumentaciju o transfernim cijenama, ali nedostaci tih sporazuma značajno utječu na poslovanje kompanije i zbog njih većina poreznih obveznika radije bira dokumentaciju nego sporazume o transfernim ciejnama. Glavni nedostaci sporazuma o transfernim cijenama su troškovi sklapanja i razdoblje trajanja sklapanja sporazuma. Osim toga, rezultati istraživanja su pokazali da zemlje koje imaju sklopljen velik broj ugovora o izbjegavanju dvostrukog oporezivanja odobravaju veći broj sporazuma o transfernim cijenama u odnosu na zemlje koje imaju manji broj ugovora o izbjegavanju dvostrukog oporezivanja (Ignat, 2017., str. 565.).

Eden i Byrnes (2018) su istraživali odnos između politike transfernih cijena i državne pomoći te su ukazali na neželjenu posljedicu primjene sporazuma o transfernim cijenama kao oblika neslužbene državne pomoći. Eden i Byrnes su tezu o sporazumu o transfernim cijenama koa oblika neformalne državne pomoći istraživali na slučajevima državne pomoći u Europskoj uniji. Rezultati njihovog istraživanja su pokazali da, u kontekstu konkurentske politike, manje razvijene države gledaju sporazume o transfernim cijenama kao oblike skrivene, diskrecijske politike privlačenja i zadržavanja direktnih stranih investicija pružajući pojedinim multinacionalnim kompanijama povlašteni porezni status (Eden i Byrnes, 2018., str. 9.). U cilju smanjivanja i onemogućavanja primjene sporazuma o transfernim cijenama kao oblika državne pomoći kojim se multinacionalnim kompanijama osigurava povlašteni porezni status, Eden i Byrnes predlažu sljedeće promjene: (a) javno objavljivanje informacija o pojedinim sporazumima o transfernim cijenama i prijelaz s jednostranih na dvostrane sporazume u kojima sudjeluju najmanje dvije porezne uprave; (b) poboljšanje kapaciteta poreznih uprava u pogledu dokumentiranja i administriranja sporazuma o transfernim cijenama; (c) ograničavanje istraga Europske komisije na slučajeve procijenjenih visokih poreznih koristi. Eden i Byrnes smatraju da Europska komisija treba prihvatiti metodologiju transfernih cijena iz sporazuma o transfernim cijenama, osim u slučajevima 
kada ne postoji nacionalna regulativa o transfernim cijenama ili kada ta regulativa nije poštivana pa su se pojavile značajne povrede regulative (Eden i Byrnes, 2018., str. 32. - 33.).

\section{METODOLOGIJA I REZULTATI ISTRAŽIVANJA}

Kao što je već ranije istaknuto svrha ovog rada je istražiti mogućnost $i$ dostupnost sporazuma o transfernim cijenama u zemljama Europske unije te utvrditi u kojoj mjeri postoji usklađenost regulative sporazuma o transfernim cijenama u zemljama Europske unije. Općenito, regulatorni okvir transfernih cijena u zemljama Europske unije temelji se na primjeni OECD-ovih smjernica o transfernim cijenama za multinacionalne kompanije i porezne uprave, a u zakonodavnom smislu problematika transfernih cijena regulirana je zakonskim propisima o porezu na dobit (Perčević, 2015., str. 638). Iako je prema rezultatima prethodnih istraživanja u većini zemalja Europske unije postojala mogućnost primjene sporazuma o transfernim cijenama (21 članica je 2015. godine zakonodavnim okvirom omogućavala primjenu sporazuma o transfernim cijenama), usklađenost regulative sporazuma o transfernim cijenama nije bila detaljnije istraživana. Implementacija zahtjeva OECD-ovog projekta umanjenja porezne osnovice i premještanja dobiti (BEPS projekt) intenzivirala je primjenu sporazuma o transfernim cijenama, i to posebice dvostranih i višestranih sporazuma, budući da su ovim projektom porezna tijela zemalja u razvoju potaknuta na intenzivniji i detaljniji nadzor transfernih cijena u svojim poreznim jurisdikcijama. Intenziviranjem nadzora transfernih cijena na međunarodnoj razini, a i unutar Europske unije, povećao se rizik transfernih cijena kako kod samih poreznih obveznika koji provode transakcije sa svojim povezanim društvima tako i kod poreznih uprava koje intenziviraju nadzor transfernih cijena kod svojih poreznih obveznika. Intenziviranje nadzora transfernih cijena od strane poreznih uprava poreznim obveznicima povećava rizik korekcije transfernih cijena, a time i porezne osnovice i obveze, te posljedično povećava njihovu izloženost dvostrukom oporezivanju. S druge strane BEPS projektom se potiče intenzivnije suradnja između poreznih uprava u pogledu zajedničkih nadzora transfernih cijena. Naposljetku, povećani nadzor transfernih cijena na međunarodnoj razini dovodi do sve većeg broja sporova vezanih za područje transfernih cijena. Jedan od učinkovitijih načina zaštite od rizika vezanih za transferne cijene su sporazumi o transfernim cijenama i to posebno dvostrani i višestrani sporazumi. Zbog intenziviranja nadzora transfernih cijena na 
međunarodnoj razini i činjenice da se u postupak nadzora uključuje dvije ili više poreznih uprava u kojima djeluju povezana društva koja provode međusobne transakcije čije transferne cijene su predmetom nadzora, javlja se sve veća potreba za harmonizacijskom regulative i postupka sklapanja i praćenja sporazuma o transfernim cijenama.

U ovom radu analizira se usklađenost regulative sporazuma o transfernim cijenama u zemljama Europske unije. Usklađenost regulative sporazuma o transfernim cijenama utvrđuje se na temelju sljedećih varijabli: (a) postojanje regulative sporazuma o transfernim cijenama u zemlji članici; (b) vrste sporazuma o transfernim cijenama koje porezni obveznici mogu sklapati; (c) postojanje naknade za sklapanjem sporazuma o transfernim cijenama i (d) prosječno vrijeme trajanja sklapanja sporazuma o transfernim cijenama. Istraživanje je obuhvatilo regulatorne okvire transfernih cijena svih zemalja članica Europske unije u 2016. i 20178. godini, dakle nakon završetka OECD-ovog BEPS projekta. Temeljem analize regulatornog okvira transfernih cijena u zemljama Europske unije za svaku zemlju članicu utvrđeno je: (a) postojanje regulative sporazuma o transfernim cijenama; (b) vrste sporazuma o transfernim cijenama koji se u zemlji mogu sklapati; (c) postojanje naknade za sklapanjem sporazuma o transfernim cijenama te (d) prosječno vrijeme trajanja sklapanja sporazuma o transfernim cijenama izraženo u mjesecima. Rezultati istraživanja regulative sporazuma o transfernim cijenama u zemljama Europske unije za 2017. godinu sistematizirani su i prikazani u sljedećoj tablici:

Tablica 1. Komparativni prikaz regulative sporazuma o transfernim cijenama u zemljama Europske unije za 2017. godinu

\begin{tabular}{|c|c|c|c|c|}
\hline \multirow[t]{2}{*}{ Zemlja članica } & \multirow[t]{2}{*}{$\begin{array}{c}\text { Vrste } \\
\text { sporazuma o } \\
\text { transfernim } \\
\text { cijenama }\end{array}$} & \multirow[t]{2}{*}{$\begin{array}{l}\text { Naknada za } \\
\text { sklapanje } \\
\text { sporazuma o } \\
\text { transfernim } \\
\text { cijenama }\end{array}$} & \multicolumn{2}{|c|}{\begin{tabular}{|c} 
Prosječno vrijeme \\
trajanja \\
sklapanja \\
sporazuma u \\
mjesecima
\end{tabular}} \\
\hline & & & $\mathbf{E U}$ & Non EU \\
\hline Austrija & $\begin{array}{c}\text { Jednostrani } \\
\text { Dvostrani } \\
\text { Višestrani }\end{array}$ & $\begin{array}{c}\text { Samo za } \\
\text { jednostrane } \\
\text { sporazume }\end{array}$ & $\mathrm{n} / \mathrm{a}$ & 17 \\
\hline Belgija & $\begin{array}{l}\text { Jednostrani } \\
\text { Dvostrani } \\
\text { Višestrani }\end{array}$ & $\mathrm{Ne}$ & 30 & 30 \\
\hline Bugarska & $\mathrm{n} / \mathrm{a}$ & $\mathrm{n} / \mathrm{a}$ & $\mathrm{n} / \mathrm{a}$ & $\mathrm{n} / \mathrm{a}$ \\
\hline Hrvatska & Jednostrani & $\mathrm{Da}$ & $\mathrm{n} / \mathrm{a}$ & $\mathrm{n} / \mathrm{a}$ \\
\hline
\end{tabular}




\begin{tabular}{|c|c|c|c|c|}
\hline & $\begin{array}{l}\text { Dvostrani } \\
\text { Višestrani }\end{array}$ & & & \\
\hline Cipar & $\mathrm{n} / \mathrm{a}$ & $\mathrm{n} / \mathrm{a}$ & $\mathrm{n} / \mathrm{a}$ & $\mathrm{n} / \mathrm{a}$ \\
\hline Češka Republika & $\begin{array}{l}\text { Jednostrani } \\
\text { Dvostrani } \\
\text { Višestrani }\end{array}$ & $\mathrm{Da}$ & $\mathrm{n} / \mathrm{a}$ & $\mathrm{n} / \mathrm{a}$ \\
\hline Danska & $\begin{array}{c}\text { Jednostrani } \\
\text { Dvostrani } \\
\text { Višestrani }\end{array}$ & $\mathrm{Da}$ & $\mathrm{n} / \mathrm{a}$ & 22 \\
\hline Estonija & $\mathrm{n} / \mathrm{a}$ & $\mathrm{n} / \mathrm{a}$ & $\mathrm{n} / \mathrm{a}$ & $\mathrm{n} / \mathrm{a}$ \\
\hline Finska & $\begin{array}{l}\text { Jednostrani } \\
\text { Dvostrani } \\
\text { Višestrani }\end{array}$ & $\begin{array}{c}\text { Samo za } \\
\text { jednostrane }\end{array}$ & 39 & $\mathrm{n} / \mathrm{a}$ \\
\hline Francuska & $\begin{array}{c}\text { Jednostrani } \\
\text { Dvostrani } \\
\text { Višestrani }\end{array}$ & $\mathrm{Ne}$ & 28 & 27 \\
\hline Njemačka & $\begin{array}{c}\text { Jednostrani } \\
\text { Dvostrani } \\
\text { Višestrani }\end{array}$ & $\mathrm{Da}$ & 36 & 47 \\
\hline Grčka & $\begin{array}{c}\text { Jednostrani } \\
\text { Dvostrani } \\
\text { Višestrani }\end{array}$ & $\mathrm{Da}$ & 20 & $\mathrm{n} / \mathrm{a}$ \\
\hline Madžarska & $\begin{array}{c}\text { Jednostrani } \\
\text { Dvostrani } \\
\text { Višestrani }\end{array}$ & $\mathrm{Da}$ & $\mathrm{n} / \mathrm{a}$ & $\mathrm{n} / \mathrm{a}$ \\
\hline Irska & $\begin{array}{l}\text { Dvostrani } \\
\text { Višestrani }\end{array}$ & $\mathrm{Ne}$ & $\mathrm{n} / \mathrm{a}$ & 44 \\
\hline Italija & $\begin{array}{l}\text { Dvostrani } \\
\text { Višestrani }\end{array}$ & $\mathrm{Ne}$ & 55 & 51 \\
\hline Latvija & Jednostrani & $\mathrm{Da}$ & $\mathrm{n} / \mathrm{a}$ & $\mathrm{n} / \mathrm{a}$ \\
\hline Litva & $\begin{array}{c}\text { Jednostrani } \\
\text { Dvostrani } \\
\text { Višestrani }\end{array}$ & $\mathrm{Ne}$ & $\mathrm{n} / \mathrm{a}$ & $\mathrm{n} / \mathrm{a}$ \\
\hline Luxemburg & $\begin{array}{c}\text { Jednostrani } \\
\text { Dvostrani } \\
\text { Višestrani }\end{array}$ & $\mathrm{Da}$ & $\mathrm{n} / \mathrm{a}$ & $\mathrm{n} / \mathrm{a}$ \\
\hline Malta & $\mathrm{n} / \mathrm{a}$ & $\mathrm{n} / \mathrm{a}$ & $\mathrm{n} / \mathrm{a}$ & $\mathrm{n} / \mathrm{a}$ \\
\hline Nizozemska & $\begin{array}{l}\text { Jednostrani } \\
\text { Dvostrani } \\
\text { Višestrani }\end{array}$ & $\mathrm{Ne}$ & $\mathrm{n} / \mathrm{a}$ & 24 \\
\hline Poljska & $\begin{array}{l}\text { Jednostrani } \\
\text { Dvostrani } \\
\text { Višestrani }\end{array}$ & $\mathrm{Da}$ & 22 & 34 \\
\hline Portugal & Jednostrani & $\mathrm{Da}$ & $\mathrm{n} / \mathrm{a}$ & $\mathrm{n} / \mathrm{a}$ \\
\hline
\end{tabular}




\begin{tabular}{|l|c|c|c|c|}
\hline & $\begin{array}{c}\text { Dvostrani } \\
\text { Višestrani }\end{array}$ & & \\
\hline Rumunjska & $\begin{array}{c}\text { Jednostrani } \\
\text { Dvostrani } \\
\text { Višestrani }\end{array}$ & Da & 18 & 18 \\
\hline Slovenija & $\begin{array}{c}\text { Jednostrani } \\
\text { Dvostrani } \\
\text { Višestrani }\end{array}$ & Da & n/a & n/a \\
\hline Slovačka Republika & $\begin{array}{c}\text { Jednostrani } \\
\text { Dvostrani } \\
\text { Višestrani }\end{array}$ & Da & n/a & n/a \\
\hline Španjolska & $\begin{array}{c}\text { Jednostrani } \\
\text { Dvostrani } \\
\text { Višestrani }\end{array}$ & Ne & 24 & 26,5 \\
\hline Švedska & $\begin{array}{c}\text { Dvostrani } \\
\text { Višestrani }\end{array}$ & Da & 37 & 37 \\
\hline Velika Britanija & $\begin{array}{c}\text { Jednostrani } \\
\text { Dvostrani }\end{array}$ & Ne & 53 & 35 \\
\hline
\end{tabular}

Izvor: Joint Transfer Pricing Forum (2018) Statistics on on APAs in the EU at the End of 2017, dostupno na:

https://ec.europa.eu/taxation customs/business/company-tax/transferpricing-eu-context/joint-transfer-pricing-forum_en (pristupljeno 24.07.2019.)

Kao što se može vidjeti u tablici 1 . u 24 zemlje članice Europske unije $(86 \%)$ postoji regulative sporazuma o transfernim cijenama, dok takva regulativa ne postoji u 4 zemlje članice (14\%). 
Slika 1. Postojanje regulative sporazuma o transfernim cijenama u zemljama Europske unije u 2017. godini

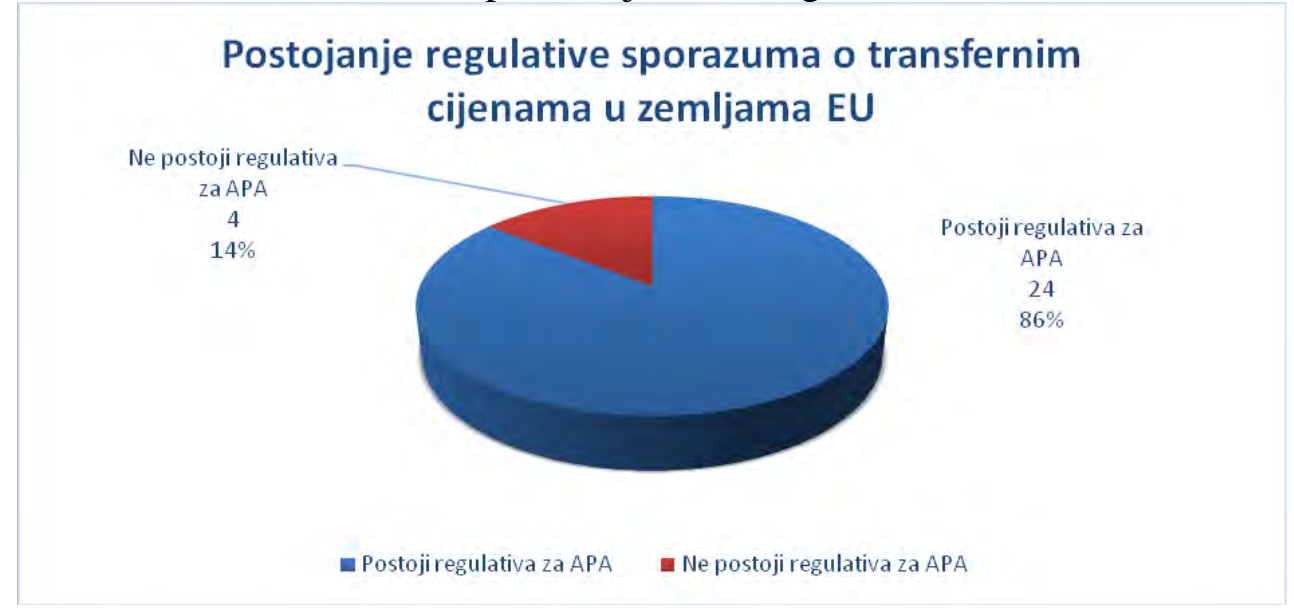

Izvor: obrada autora

U usporedbi s rezultatima istraživanja iz 2015. godine kada je 21 zemlja članici imala regulative sporazuma o transfernim cijenama te s podacima iz 2016. godine kada su 23 zemlje članice imale regulativu sporazuma o transfernim cijenama, uočava se postupno povećanje zemalja članica koje implementiraju regulativu sporazuma o transfernim cijenama u svoje zakonodavne okvire. To je u skladu s implementacijom rezultata i zahtjeva OECD-ovog BEPS projekta te prepoznavanjem sporazuma o transfernim cijenama kao učinkovitog instrumenta zaštite od rizika transfernih cijena, kako kod poreznih obveznika tako i kod poreznih uprava zemalja članica Europske unije.

Kada je riječ o vrstama sporazuma o transfernim cijenama koje porezni obveznici mogu sklapati u pojedinim zemljama Europske unije, rezultati provedenog istraživanja za 2017. godinu pokazuju da u 19 zemalja Europske unije (79\%) porezni obveznici mogu sklapati sve tri vrste sporazuma o transfernim cijenama (jednostrane, dvostrane i višestrane sporazume o transfernim cijenama), u 3 zemlje (13\%) mogu sklapati dvostrane i višestrane sporazume te u jednoj zemlji (4\%) mogu sklapati jednostrane i dvostrane sporazume i u jednoj (4\%) samo jednostrane sporazume. 
Slika 2. Vrste sporazuma o transfernim cijenama koje porezni obveznici mogu sklapati u zemljama Europske unije

\section{Vrste sporazuma o transfernim cijenama u \\ dvostrani i \\ zemljama EU}

\section{višestrani ; $3 ; 13 \%$}

jednostrani i

dvostrani; $1 ; 4 \%$

jednostrani ; $1 ; 4 \%$

jednostrani, dvostrani i višestrani

jednostrani

jednostrani,

dvostrani i

višestrani ; 19; $79 \%$

- jednostrani i dvostrani

Inostrani i višestrani

Izvor: obrada autora

U usporedbi s rezultatima istraživanja za 2016. godinu, u 2107. godini se u jednoj zemlji više u odnosu na 2016. godinu mogu sklapati sve tri vrste sporazuma o transfernim cijenama, a ta razlika proizlazi iz one zemlje (Slovenija) koja je počela primjenjivati regulativu sporazuma o transfernim cijenama od 2017. godine.

Rezultati istraživanja regulative sporazuma o transfernim cijenama pokazuju da velika razlika između zemalja Europske unije postoji kod naknada za sklapanjem sporazuma o transfernim cijenama. Naime, u 14 zemalja Europske unije (59\%) regulativom sporazuma o transfernim cijenama predviđeno je plaćanje naknade za sklapanjem sporazuma, u 2 zemlje (8\%) ta se naknada plaća samo za jednostrane sporazume, dok se u 8 zemalja (33\%) naknada za sklapanjem sporazuma o transfernim cijenama ne plaća. Radi jednakog tretmana poraznih obveznika u svim poreznim jurisdikcijama zemalja Europske unije, bit će potrebno dodatno harmonizirati pitanje naknada za sklapanjem sporazuma o transfernim cijenama. 
Slika 3. Postojanje naknada za sklapanjem sporazuma o transfernim cijenama u zemljana Europske unije u 2017. godini

\section{NAKNADAZA SPORAZUME O TRANSFERNIM CIJENAMA U ZEMLJAMA EU}

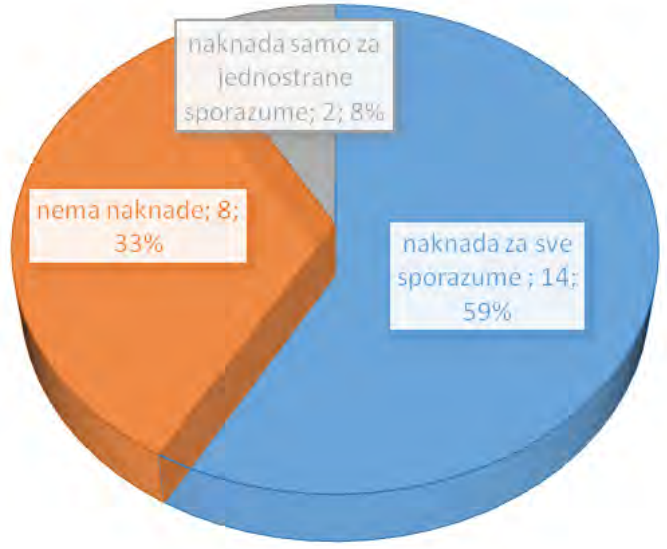

Dnaknada za sve sporazume

nemanaknade

naknada samo za jednostrane sporazume

Izvor: obrada autora

U usporedbi s rezultatima istraživanja za 2016. godinu, u 2017. godini se u jednoj zemlji više poreznim obveznicima naplaćuje naknada za sklapanje sporazuma o transfernim cijenama, a ta razlika proizlazi iz one zemlje (Slovenija) koja je počela primjenjivati regulativu sporazuma o transfernim cijenama od 2017. godine.

Analiza vremenskog razdoblja trajanja sklapanja sporazuma o transfernim cijenama u zemljama Europske unije pokazala je postojanje značajnih razlika između pojedinih zemalja. Rezultati istraživanja su pokazali da je u 2017. godini u zemljama Europske unije vrijeme trajanja sklapanja sporazuma o transfernim cijenama variralo od 18 mjeseci do 55 mjeseci za sporazume unutar Europske unije odnosno od 17 mjeseci do 51 mjeseca za sporazume izvan Europske unije. Prosječno vrijeme trajanja sklapanja sporazuma o transfernim cijenama u zemljama Europske unije u 2017. godini je 32,91 mjeseci za sporazume unutar Europske unije (uz standardnu devijaciju od 12,55 mjeseci) odnosno 31,73 mjeseci za sporazume izvan Europske unije (uz standardnu devijaciju 10,85 mjeseci). S obzirom na relativno visoku standardnu devijaciju, korisnije je u analizi vremena trajanja sklapanja sporazuma po transfernim cijenama koristiti medijan. Medijan vremena trajanja sklapanja sporazuma o transfernim cijenama u zemljama Europske unije u 2017 godinu iznosio je 30 mjeseci i za 
sporazuma unutar i za sporazuma izvan Europske unije. Drugim riječima, u $50 \%$ zemalja članica trajanje sklapanja sporazuma o transfernim cijenama je iznosilo 30 mjeseci i manje od 30 mjeseci, a u preostalih $50 \% 30$ i više od 30 mjeseci. Koeficijent zaobljenosti distribucije vremena trajanja sklapanja sporazuma o transfernim cijenama u zemljama Europske unije u 2017. godini pokazuje blago pozitivnu asimetričnu distribuciju i za sporazume unutar i za sporazume izvan Europske unije.

Tablica 2. Deskriptivno statistička analiza vremena trajanja sklapanja sporazuma o transfernim cijenama u zemljama Europske unije u 2017. godini

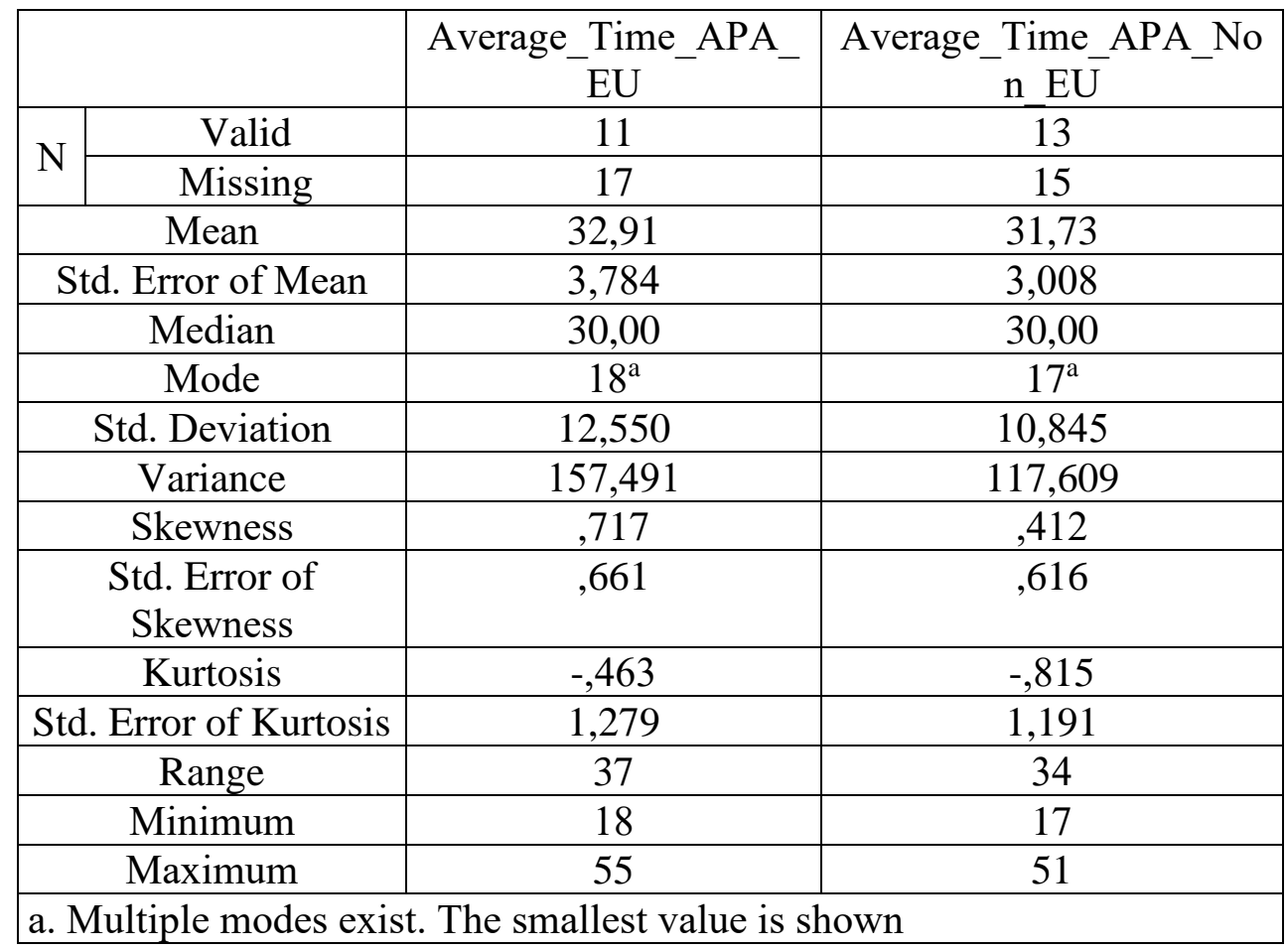

Izvor: obrada autora

U usporedbi s podacima iz 2017. godine, u 2016. godini vrijeme trajanja sklapanja sporazuma o transfernim cijenama variralo je od 15 mjeseci do 61 mjeseca za sporazume unutar Europske unije odnosno od 18 mjeseci do 52 mjeseca za sporazume izvan Europske unije. Sklapanje sporazuma o transfernim cijenama u zemljama Europske unije prosječno je trajalo 30,44 mjeseci za sporazume unutar Europske unije (uz standardnu devijaciju od 13,15 mjeseci) odnosno 31,38 mjeseci za sporazume izvan Europske unije 
(uz standardnu devijaciju od 11,22 mjeseca). Medijan vremena trajanja sklapanja sporazuma o transfernim cijenama u zemljama Europske unije iznosi 27,50 mjeseci za sporazume unutar Europske unije odnosno 30 mjeseci za sporazume izvan Europske unije. Koeficijent zaobljenosti distribucije vremena trajanja sklapanja sporazuma o transfernim cijenama u zemljama Europske unije u 2016. godini pokazuje blago pozitivnu asimetričnu distribuciju i za sporazume unutar i za sporazume izvan Europske unije.

Tablica 3. Deskriptivno statistička analiza vremena trajanja sklapanja sporazuma o transfernim cijenama u zemljama Europske unije u 2016. godini

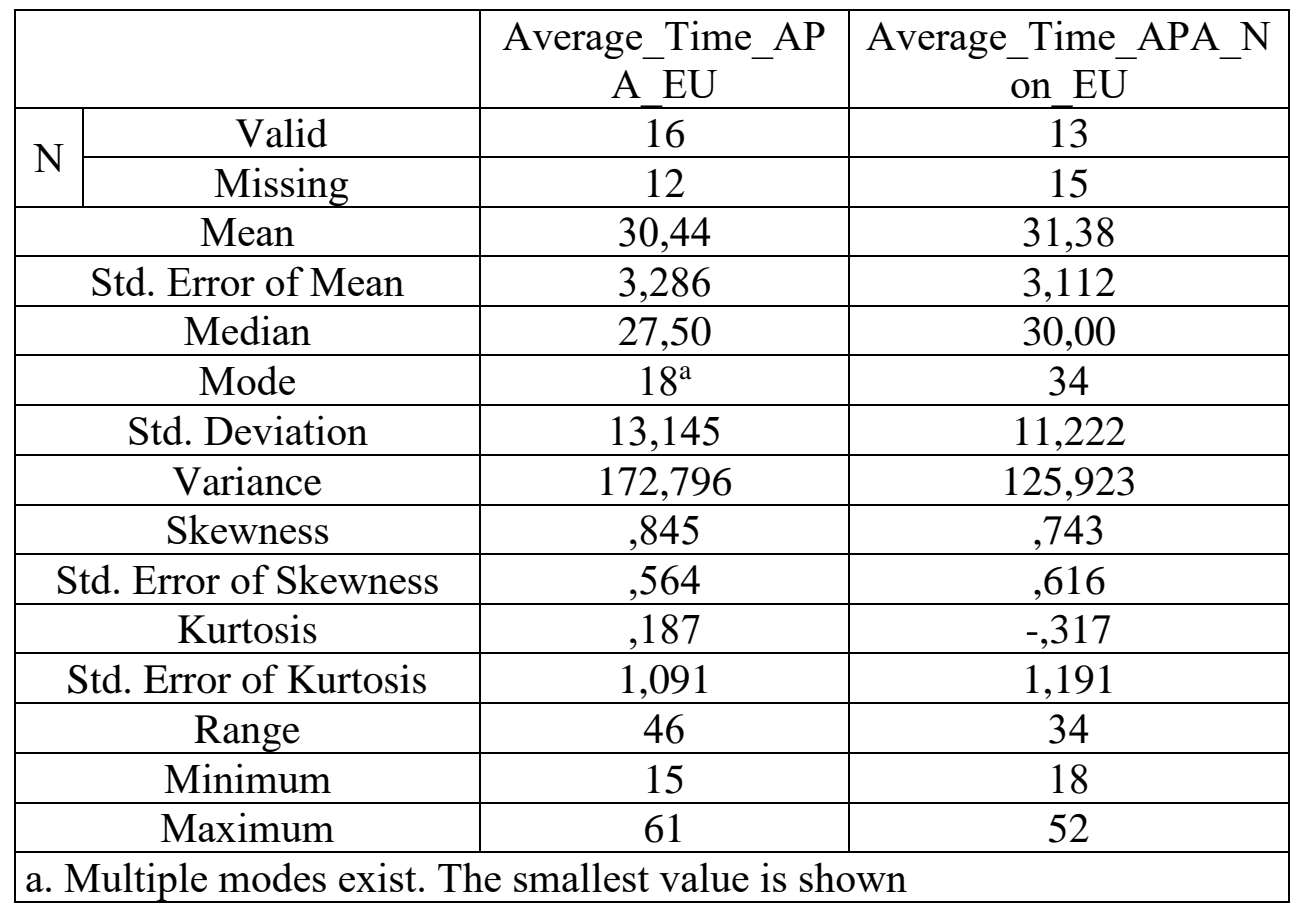

Izvor: obrada autora

Usporedbom podataka o vremenu trajanja sklapanja sporazuma o transfernim cijenama u zemljama Europske unije u 2016. i 2017. godini može se zaključiti da kod sporazuma izvan Europske unije ne postoje značajne razlike u vremenu trajanja sklapanja sporazuma, dok je kod sporazuma unutar Europske unije vidljivo blago produljenje vremena trajanja sklapanja sporazuma (temeljem aritmetičke sredine i medijana). Razlog tom blagom povećanju vremena trajanja sklapanja sporazuma 
proizlazi iz intenzivnije primjene sporazuma o transfernim cijenama u onim zemljama koje su relativno nedavno implementirale regulativu sporazuma o transfernim cijenama te povećanju broja zahtjeva za sklapanjem sporazuma zbog implementacije zahtjeva OECD-ovog BEPS programa.

Temeljem provedenog istraživanja $i$ analize regulative sporazuma o transfernim cijenama u zemljama Europske unije može se zaključiti da postoji visoka usklađenost $\mathrm{u}$ pogledu formalnog postojanja regulative sporazuma o transfernim cijenama te primjene vrsti sporazuma o transfernim cijenama. Određena poboljšanja u smislu usklađenosti regulative sporazuma o transfernim cijenama u zemljama Europske unije moguća su u području reguliranja naknada za sklapanjem sporazume te vremenu trajanja sklapanja sporazuma, iako samo vrijeme trajanja ovisi, između ostalog, i o raspoloživim resursima nacionalne porezne uprave.

\section{ZAKLJUČAK}

Sporazumi o transfernim cijenama su sporazumi između poreznih obveznika te jedne ili više nacionalnih poreznih uprava kojim se dogovara skup kriterija za određivanje transfernih cijena u transakcijama između povezanih društava koje su predmetom nadzora poreznih uprava prije nastanka tih transakcija. Postoji tri vrste sporazuma o transfernim cijenama, a to su jednostrani, dvostrani i višestrani sporazumi. Jednostrani sporazumi o transfernim cijenama su oni kod kojih kao sporazumna strana sudjeluje samo jedna porezna uprava, dvostrani su oni kod kojih sudjeluju dvije porezne uprave, a višestrani oni kod kojih sudjeluje više od dvije porezne uprave. Sporazumi o transfernim cijenama su u suvremenim uvjetima učinkovit instrument zaštite od rizika transfernih cijena kako za same porezne obveznike tako i za same porezne uprave. Naime, sporazumom o transfernim cijenama porezni obveznici se štite od korekcija transfernih cijena, a time i korekcija porezne osnovice i porezne obveze, koje mogu rezultirati dvostrukim oporezivanjem. S druge strane, poreznim upravama je temeljem sporazuma o transfernim cijenama znatno olakšan postupak nadzora transfernih cijena te oni doprinose učinkovitijem korištenju resursa poreznih uprava. Nadzor transfernih cijena u slučaju primjene sporazuma o transfernim cijenama svodi se, uglavnom, na nadzor poštivanja sporazumnih uvjeta. 
Atraktivnosti i široj primjeni sporazuma o transfernim cijenama uvelike je doprinio OECD-ov projekt umanjenja porezne osnovice i premještanja dobiti (BEPS projekt) koji je potaknuo porezne uprave zemalja u razvoju na intenzivniji nadzor transfernih cijena u njihovim poreznim jurisdikcijama. Kao rezultat implementacije zaključaka i zahtjeva BEPS projekta, intenzivirao se nadzor transfernih cijena $u$ transakcijama između povezanih društava na međunarodnoj razini koji je za posljedicu iznjedrio povećanje izloženosti dvostrukom oporezivanju poreznih obveznika te povećanje sporova vezanim uz transferne cijene na međunarodnoj razini. U cilju zaštite od potencijalne mogućnosti dvostrukog oporezivanja temeljem transfernih cijena, porezni obveznici su sporazume o transfernim cijenama prepoznali kao učinkovit i primjeren instrument zaštite. Pri tome, veću učinkovitost zaštite od rizika transfernih cijena i dvostrukog oporezivanja imaju dvostrani i višestrani sporazumi u odnosu na jednostrane. Povećanje broja zahtjeva i intenziviranje primjene sporazuma o transfernim cijenama potaknulo je razvoj i implementaciju regulative sporazuma o transfernim cijenama kako u pojedinim zemljama tako i na međunarodnoj razini. Prijedlog sklapanje i primjene sporazuma o transfernim cijenama na međunarodnoj razini dan je u okviru OECD-ovih smjernica o transfernim cijenama za multinacionalne kompanije i porezne uprave revidiranih nakon implementacije rezultata i zaključaka BEPS projekta. I dok su razvijene zemlje svijeta imale implementiranu regulativu sporazuma o transfernim cijenama u svom nacionalnom zakonodavnom okviru, zemlje u razviju su tek završetkom BEPS projekta počele $s$ intenzivnijim razvojem i implementacijom regulative sporazuma o transfernim cijenama.

U ovom radu provedeno je istraživanje regulative sporazuma o transfernim cijenama u zemljama članicama Europske unije s ciljem utvrđivanja njezine usklađenosti u zemljama Europske unije. Istraživanje regulative sporazuma o transfernim cijenama temeljilo se na sljedećim varijablama: (a) postojanju formalne regulative sporazuma o transfernim cijenama u zemlji članici; (b) vrste sporazuma o transfernim cijenama koje je moguće sklopiti u zemlji članici; (c) postojanje naknade za sklapanjem sporazuma o transfernim cijenama u zemlji članici te (d) vremenu trajanja sklapanja sporazuma o transfernim cijenama. Rezultati provedenog istraživanja su pokazali da $85 \%$ zemalja Europske unije ima ugrađenu formalnu regulativu sporazuma o transfernim cijenama $u$ svojem nacionalnom zakonodavstvu te da $79 \%$ zemalja Europske unije dozvoljava sklapanje i primjeni svih triju vrsta sporazuma o transfernim cijenama. Stoga, u kontekstu postojanja formalne regulative i primjene vrsti sporazuma o transfernim cijenama u zemljama Europske unije postoji vrlo visoka usklađenost. Manja razina usklađenosti 
postoji kod naknada za sklapanje sporazuma o transfernim cijenama, budući da rezultati istraživanja pokazuju da 59\% zemalja zahtijeva plaćanje naknade za sklapanjem sporazuma o transfernim cijenama, dok je najveća razlika u pogledu vremena trajanja sklapanje sporazuma o transfernim cijenama između pojedinih zemalja Europske unije. Poboljšanja u kontekstu usklađenosti regulative sporazuma o transfernim cijenama u zemljama Europske unije moguća su u području naknada za sklapanjem sporazuma te vremenu trajanja sklapanja sporazuma. Međutim, kada je riječ o vremenu trajanja sklapanja sporazuma, u obzir se moraju uzeti raspoloživost resursa pojedinih nacionalnih poreznih uprava kao faktor ograničenja smanjivanja vremena trajanja sklapanja sporazuma.

\section{LITERATURA}

1. Bakran, D., Botica, A., Cinotti, K., Gulin, D., Milčić, M., Orlović, L., Perčević, H., Prtain, Š., Škara, M. (2018) Porez na dobit poduzetnika i neprofitnih organizacija, Zagreb, HZRiF

2. Borkowski, S., Transfer Pricing Agreements: Current Status by Country, International Tax Journal, 26(2) Spring 2000

3. EU Joint Transfer Pricig Forum (2018) Statistics on APAs in the EU at the End of 2016, dostupno na: https://ec.europa.eu /taxation_customs/sites/taxation/files/2016_jptf_apa_statistics_en.pd f, pristupljeno 24.07.2019.

4. EU Joint Transfer Pricing Forum (2018) Statistics on APAs in the EU at the End of 2017, dostupno na: https://ec.europa.eu /taxation_customs/sites/taxation/files/statistics_on_advance_pricing_ agreements_2017_en.pdf, pristupljeno 24.07.2019.

5. Fan, X. (2008) Difficulties in Pressing Forward Advance Pricing Agreement (APA) in China, Asian Social Science Vol. 4, No. 11, 53-58

6. Gulin, D., Perčević, H. (2013) Financijsko računovodstvo - izabrane teme, Zagreb, HZRiF

7. Gulin, D., Janković, S., Dražić Lutilsky, I., Perčević, H., Peršić, M., Vašiček, V. (2011) Upravljačko računovodstvo, Zagreb, HZRiF

8. Eden, L., Byrnes, W. (2018) Transfer pricing and state aid: the unintended consequences of advance pricing agreements, TRANSNATIONAL CORPORATIONS Volume 25, 2018, Number 2, 9-33 
9. Hickman K., E. (1998) Should Advance Pricing Agreements be Published?, Northwestern Journal of International Law \& Business, vol. 19., issue 1.

10. Ignat (Neacsu) I. (2017) Advance Pricing Agreements and Double Taxation - Key Concepts in the Context of Transfer Pricing, "Ovidius" University Annals, Economic Sciences Series, Volume XVII, Issue 2 /2017, 565-570

11. Kortebusch, P. (2014) Should multinational companies request an advance pricing agreement (APA) - or shouldn't they?, Quantitative Research in Taxation - Discussion Papers, arqus Discussion Paper No. 173, 1-37

12. KPMG (2017) Advanced Pricing Agreements: The why and the how of here and now, KPMG LLP and KPMG International

13. Narodne novine (2017) Pravilnik o postupku sklapanja prethodnog sporazuma o transfernim cijenama, Narodne novine 42/17, Zagreb

14. Narodne novine (2018) Zakon o porezu na dobit, Narodne novine $177 / 04-106 / 18$

15. Narodne novine (2019) Pravilnik o porezu na dobit, Narodne novine 95/05-1/19

16. OECD (2017) OECD Transfer Pricing Guidelines for Multinational Enterprises and Tax Administrations, OECD Publishing, Paris.

17. OECD (2013) Action Plan on Base Erotion and Profit Shifting, OECD Publishing.

18. Osborn, J. and Khripounova, E. (2016) Advance Pricing Agreements In the Post-BEPS Era, Tax Notes, vol. 150, No 10, March 7, 2016, p. 1179-1184

19. Perčević, H. (2015) Usklađenost regulatornog okvira transfernih cijena u zemljama Europske unije, Ekonomska misao i praksa vol. XXIV, No 2. 627-650 


\title{
Hrvoje Perčević, PhD
}

Faculty of Economics and Business, University of Zagreb, Zagreb, Croatia hpercevic@efzg.hr

\section{COMPARATIVE PRESENTATION OF THE REGULATION OF ADVANCED PRICING AGREEMENTS IN THE EUROPEAN UNION COUNTRIES}

Received: July 15, 2019

Accepted: October 7, 2019

Review

\begin{abstract}
Transfer prices are the prices on which transactions between connected persons occur, usually between affiliated companies that are members of the same group. By globalization of business and continuous business mergers of companies operating in the global market, transfer prices become a significant instrument for the allocation of consolidated profits between affiliated companies within the International group. In order to prevent manipulation with transfer pricing, the tax administration seeks to continuously carry out supervision of transactions between affiliates and transfer pricing, whereby such transactions are realised, notably by analysing and controlling Transfer pricing documentation drawn up by the related companies (taxpayers). However, due to the limited resources of the tax administration, they are not able to carry out full and detailed transfer pricing controls in all transactions between related companies within their jurisdiction, which the tax administrations face with the existence of a significant risk transfer pricing. At risk of transfer pricing is assumed the risk of non-compliance of transfer pricing in transactions between related companies with an arm's length principle and is inherent in both tax administrations and related companies that are taxpayers. The risk of transfer pricing at tax payers relates to the risk of tax base correction and, consequently, to the correction of tax liabilities due to transfer pricing established contrary to an arm's length principle. Therefore, both tax administrations and related companies (taxpayers) strive to manage the risk of transfer pricing in order to minimise it as much as possible. One of the most significant risk management instruments of transfer pricing are the advanced pricing agreements concluded between the related companies (taxpayers) and one or more tax administrations. The advanced pricing
\end{abstract}


agreement defines in advance the assumptions, conditions, criteria and methods for determining transfer pricing in specified transactions between related companies for a given period of time, which significantly minimises the transfer pricing risk at both, taxpayers and tax administrations.

This paper analyzes and systematises the possibility and availability of advanced pricing agreements in the European Union countries and explores the extent to which the regulation of transfer pricing arrangements in the European Union is compliant. The results of the survey showed that in most of the European Union Member States, the regulatory framework enables the application of advanced pricing agreement and that in most countries of the European Union are available all three types of advanced pricing agreements. In terms of regulation, the European Union countries differ in the calculation of fees for the conclusion of the advanced pricing agreement, as well as in the time-limit for the conclusion of the advanced pricing agreement.

Keywords: advanced pricing agreements, transfer pricing, related companies, transfer price risk, tax administration

JEL: M40, M41 